\title{
Streamflow Losses through Karst Features in the Upper Peace River Hydrologic Area, Polk County, Florida, May 2002 to May 2003
}

\section{Introduction}

In October 2001, the U.S. Geological Survey (USGS) in cooperation with the Southwest Florida Water Management District (SWFWMD) began a study to evaluate the distribution, timing, and volume of surface-water to ground-water exchange in the Upper Peace River Hydrologic Area in Polk County, Florida (fig. 1). Historically, ground-water levels in

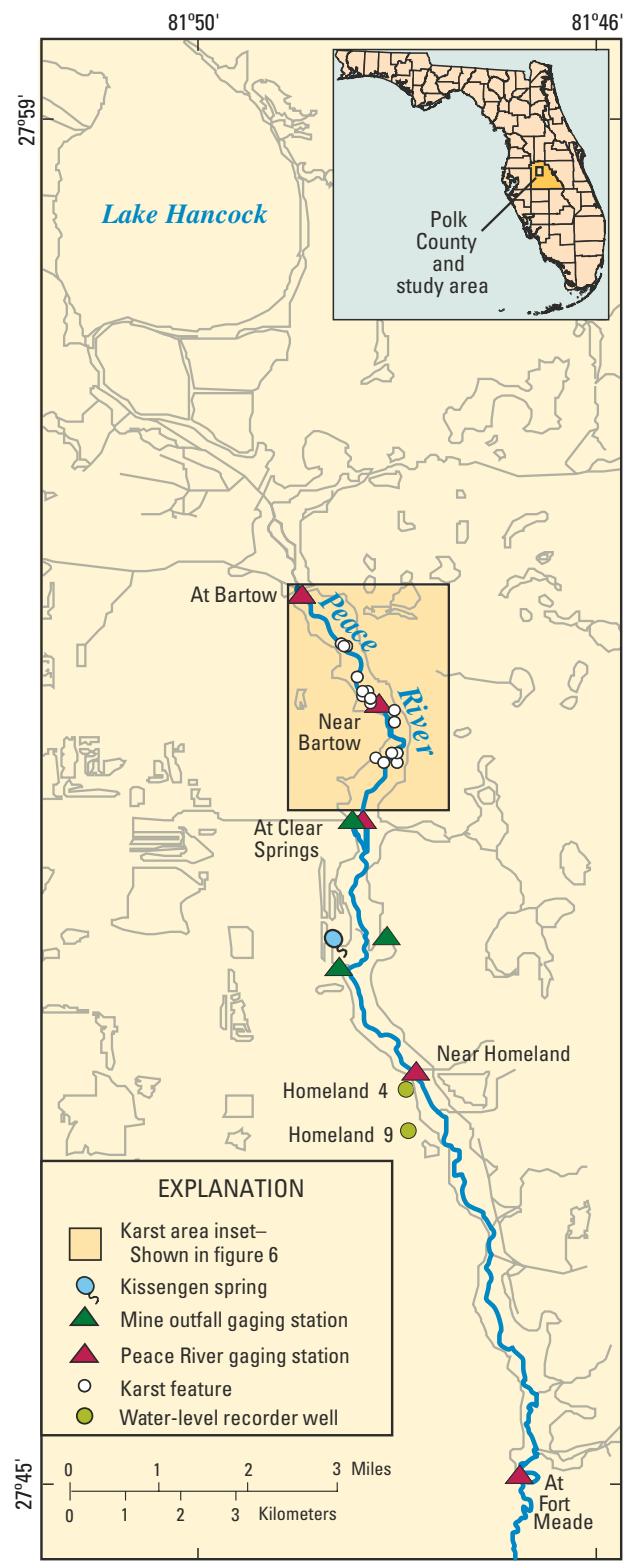

Figure 1. Upper Peace River Hydrologic Area, Polk County, Florida.

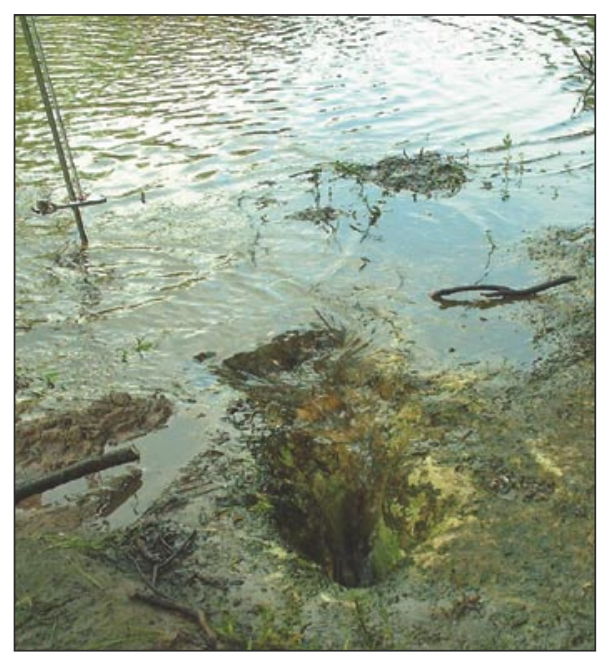

Figure 2. Fricano fracture.

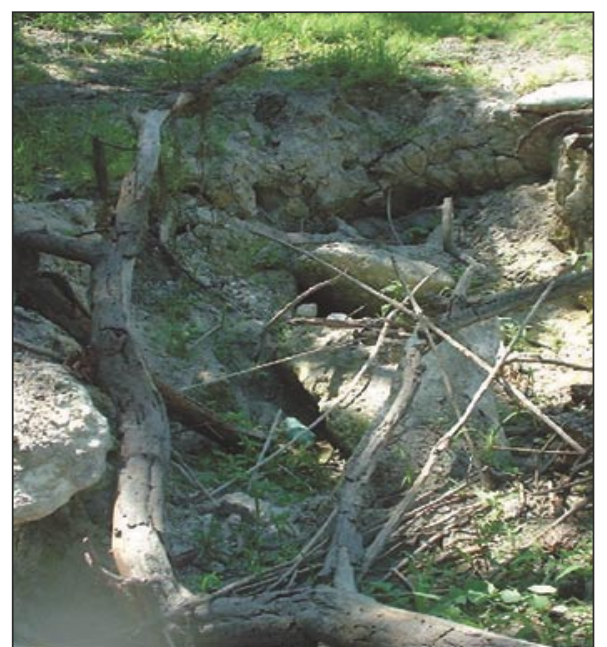

Figure 3. Midway sink.

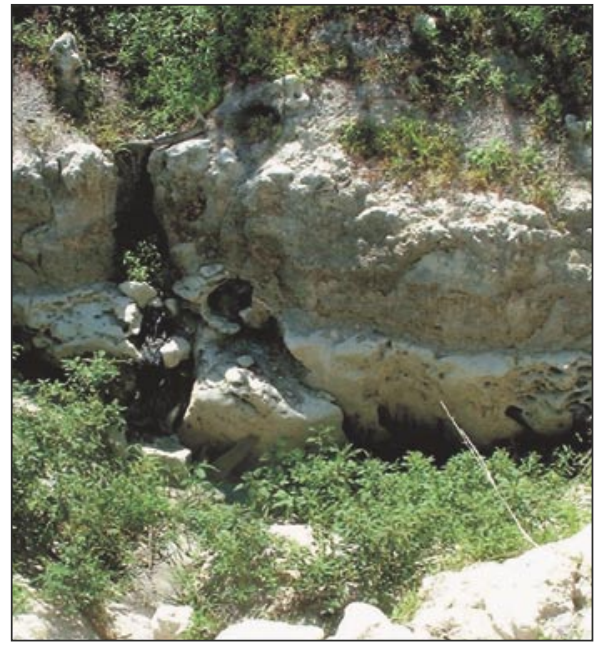

Figure 4. Dover sink. this area were above surface-water levels (gaining stream), wells and second-order magnitude springs flowed, and tributaries drained the surrounding highlands (scarps) (Stewart, 1966). Strip-mining of phosphate ore (1) altered the landscape, (2) changed the natural surface-water drainage patterns, and (3) changed the ground-water flow patterns by removing the upper $50 \mathrm{ft}$ (feet) of sediments and lowering the potentiometric surface of the aquifers. Today, this area of the Peace River appears to be a losing stream. Streamflow losses are predominately through karst features found in the low-water channel and the flood plain.

\section{Karst Features}

Locations, surface orientations, and dimensions of prominent karst features were measured in mid-May 2002 when reaches of the river were dry. Examples of features are shown in the photographs. Fricano fracture (fig. 2) is a coalescing group of vertical pipes; Midway sink (fig. 3) is a collapsing sinkhole with small fractures near the base; Dover sink (fig. 4) at the base of the outcrop is located at the end of a 200-ft-long distributary in the flood plain; and the crevasses (fig. 5) includes multiple

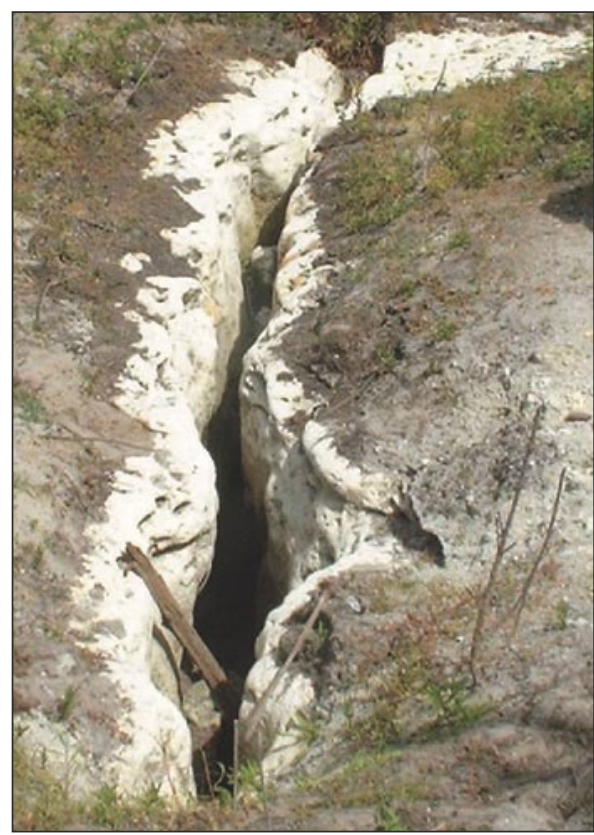

Figure 5. The crevasses. 
fractures-the largest is 26 feet long and spans the riverbed. The spatial distribution of the karst features is shown in figure 1. Vertically, these features are present at the contact between the Peace River and Arcadia Formations. The largest karst feature mapped is the catacombs, which is located in the flood plain (fig. 6). This feature is composed of numerous interconnected horizontal and vertical fractures that show evidence of scouring by moving water; some of the openings are large enough for a person to enter. Numerous smaller features also are found in the channel and the flood plain.

\section{Streamflow Losses During Late Spring 2002}

The Peace River ceased flowing at the Bartow gaging station on May 12, 2002. Intermittent flow in the river was observed between May 19 and June 25 with the commencement of summer rain, and steady flow resumed again in late June 2002 as the frequency of summer storms increased (fig. 7). During the period of intermittent flow, surface water was lost to the ground-water system via karst features downstream from the Bartow gaging station; the length of the

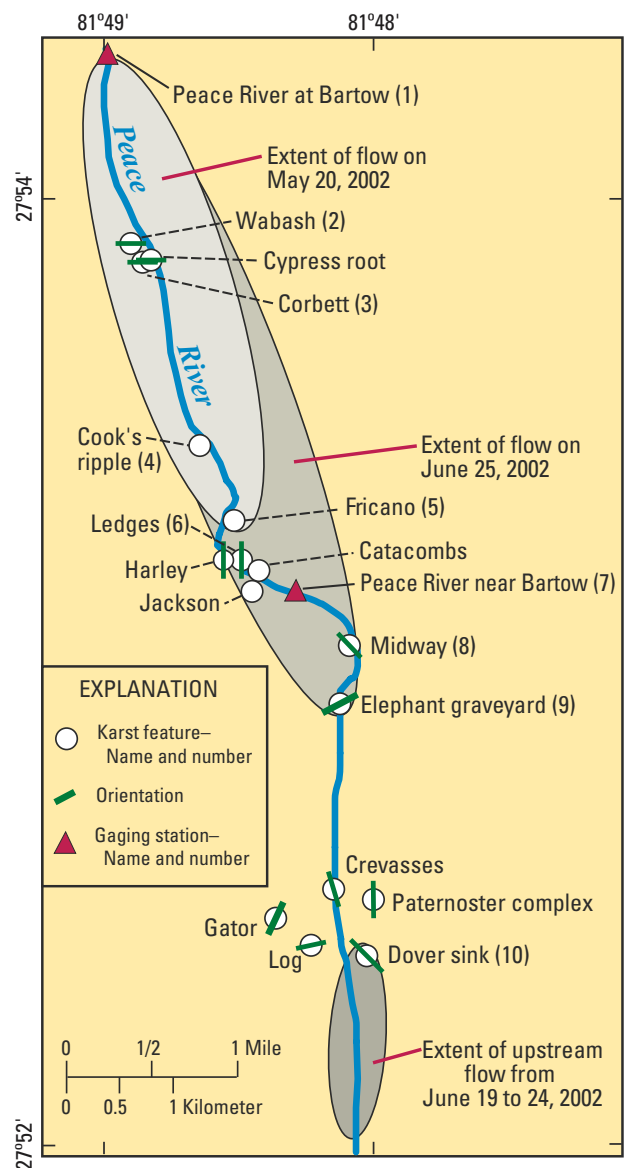

Figure 6. Extent of the Peace River losing flow to selected karst features.

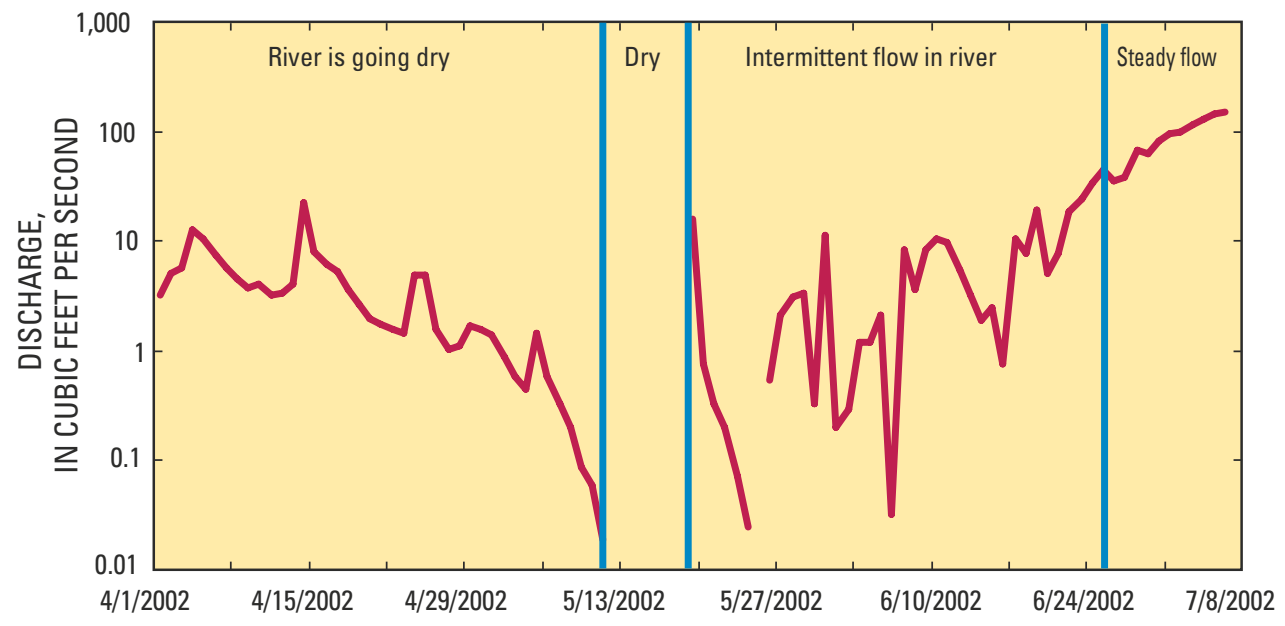

Figure 7. Streamflow hydrograph for the Peace River at Bartow gaging station. river reach containing flow increased over time but was dry between karst features 9 and 10 (fig. 6). Interestingly, downstream from feature 10, flow was reversed along a low-lying section of the riverbed and exited the river at a distributary leading to Dover sink (fig. 6). The source of the water was Sixmile Creek, a mine outfall.

Streamflow losses through karst features were measured at selected sites (table 1 and fig. 6). Table 1 shows the instantaneous volumes of flow lost to selected features along the reach of the Peace River riddled with karst. In table 1, values shown in blue indicate the farthest downstream feature to receive flow from the Peace River on that day, and values shown in red indicate upstream flow in the riverbed. Quantifying total losses between individual measuring sections on the river during a specific day was not possible because discharge at a given measuring section was not at steady state-some values changed by more than 200 percent during a day. However, records from the gaging station at Bartow indicated that streamflow losses during late spring 2002 ranged from 2 to 30 cubic $\mathrm{ft}$ per second $\left(\mathrm{ft}^{3} / \mathrm{s}\right)$; all of the water was lost upstream from, or at, site 9 (table 1 and fig. $6)$.

\section{Streamflow Losses During Late Spring 2003}

A seepage run was conducted on May 13 to 14, 2003, at the end of the dry season. The daily mean discharge at the Bartow station (upper end) and the Fort Meade station (lower end) fell 2 and $8 \mathrm{ft}^{3} / \mathrm{s}$, respectively (fig. 8). The seepage run was designed to quantify gains and losses to the river during a steady-state period, representing low ground-water levels. To maintain steadystate conditions of surface-water flow, the control structures were not adjusted during the seepage run. The discharge measurements were made using either a standard (type AA) or a pygmy current meter and standard USGS streamflow measuring techniques. Synoptic measurements of streamflow were made at 21 cross sec-
Table 1. Instantaneous discharge at selected sites in the Upper Peace River Hydrologic Area Site Numbers

\begin{tabular}{ccrrrrrrrrrc}
\hline Date & \multicolumn{1}{c}{$1^{1}$} & $1^{2}$ & 2 & 3 & 4 & 5 & 6 & 7 & 8 & 9 & 10 \\
\hline $5 / 20 / 02$ & $17-0.7$ & 5.5 & 7.3 & 2.5 & --- & 0.2 & Dry & Dry & Dry & Dry & Dry \\
\hline $6 / 11 / 02$ & 11.0 & 11.0 & 12.6 & 7.7 & --- & --- & 1.2 & Dry & Dry & Dry & Dry \\
\hline $6 / 14 / 02$ & $3.2-1.9$ & 2.5 & 4.5 & 1.2 & 0.8 & 0.2 & Dry & Dry & Dry & Dry & Dry \\
\hline $6 / 19 / 02$ & $2.8-20$ & 7.7 & --- & --- & --- & --- & --- & --- & --- & --- & 2.5 \\
\hline $6 / 20 / 02$ & $19-5.1$ & 8.6 & --- & --- & --- & --- & 5.5 & Dry & Dry & Dry & 5.1 \\
\hline $6 / 24 / 02$ & $24-34$ & 27.0 & --- & --- & --- & --- & 12.2 & 4.7 & 0.9 & Dry & 2.9 \\
\hline $6 / 25 / 02$ & $27-44$ & 30.0 & 28.1 & 22.6 & --- & --- & --- & --- & 5.6 & 2.0 & --- \\
\hline
\end{tabular}

[discharge, in cubic feet per second; site numbers shown in figure 6; ---, site not measured; blue numbers indicate the farthest downstream feature receiving flow on that date; increasing or decreasing range for site 1 indicates rising or falling discharge, respectively; red numbers indicate flow is upstream and leaves the river via a distributary] 


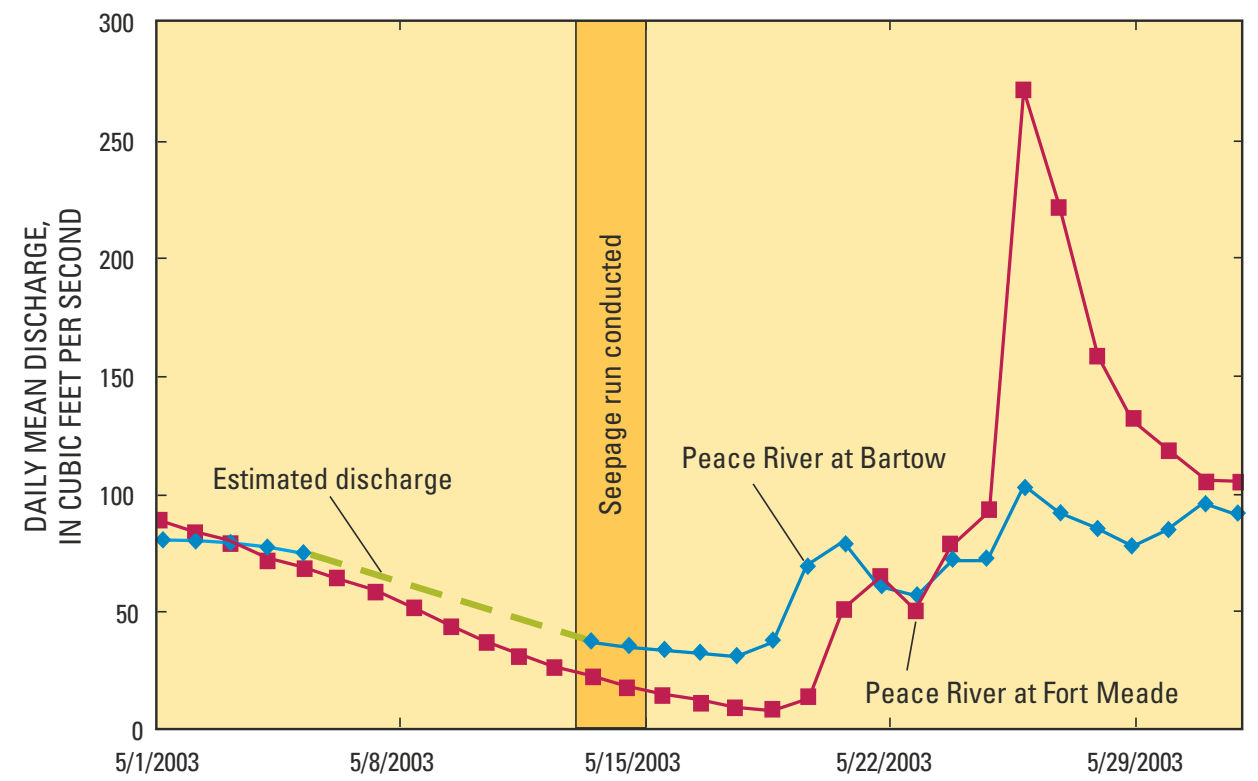

Figure 8. Streamflow hydrographs for the Peace River at Bartow and at Fort Meade gaging stations, May 2003.

tions along a 13-mile stretch of the river. Thirteen of the sections were on the Peace River; surface-water inflows from eight mine outfalls and tributaries also were measured (fig. 9). The increase or decrease in stream flow (differences in instantaneous discharge) between measurement sites that could not be accounted for through tributary influx or out-of-stream diversions was assumed to be the net volume of water exchanged between the river and the ground-water system (Simonds and Sinclair, 2002, p. 16).

During the May 2003 seepage run (fig. 10), decreasing streamflow was assumed to reflect seepage to the ground-water system. The error bars provided a way to separate measurement error from changes in stream flow. The inherent error in a "fair" discharge measurement in a natural river environment is estimated at \pm 5 percent (Rantz and others, 1982). Changes in discharge greater than the range span by the error bars were accepted as net changes. Losses were insignificant (less than $2 \mathrm{ft}^{3} / \mathrm{s}$ ) between sites 1 and 2. No losses were measured between sites 2 and 4 . Streamflow losses equaling $6 \mathrm{ft}^{3} / \mathrm{s}$ were measured between sites 4 and 5 . Streamflow losses equaling $10 \mathrm{ft}^{3} / \mathrm{s}$ were measured between sites 7 and 11. The Clear Springs station (site 11) had the lowest discharge during the seepage run. Three mine outfalls and a drainage ditch contributed $7 \mathrm{ft}^{3} / \mathrm{s}$ of inflow to the Peace River between the Clear Springs (site 11) and Homeland (site 16) stations. Two tributaries contributed $3 \mathrm{ft}^{3} / \mathrm{s}$ of inflow to the Peace River between sites

26 and 31. Streamflow losses primarily occur along the reach between the Bartow and Clear Springs stations, corresponding to locations of prominent karst features (fig. 9 and 10).

\section{Potential for Surface-Water and Ground-Water Exchanges}

The potential and rate of exchange of water between the surface-water and groundwater systems is a function of the difference between the river stage and aquifer head. Streamflow losses will occur whenever the river stage exceeds the aquifer head, but the rate depends on the magnitude of the difference, the conductivity of riverbed deposits, and the saturated area of the channel (Simonds and Sinclair, 2002, p. 23). The difference between river stage and aquifer head along the Peace River is not constant throughout the year; it fluctuates between wet and dry seasons, and the transient nature of these changes along the river is poorly known. Additionally, periodic water-level measurements from existing wells in the Upper Peace River

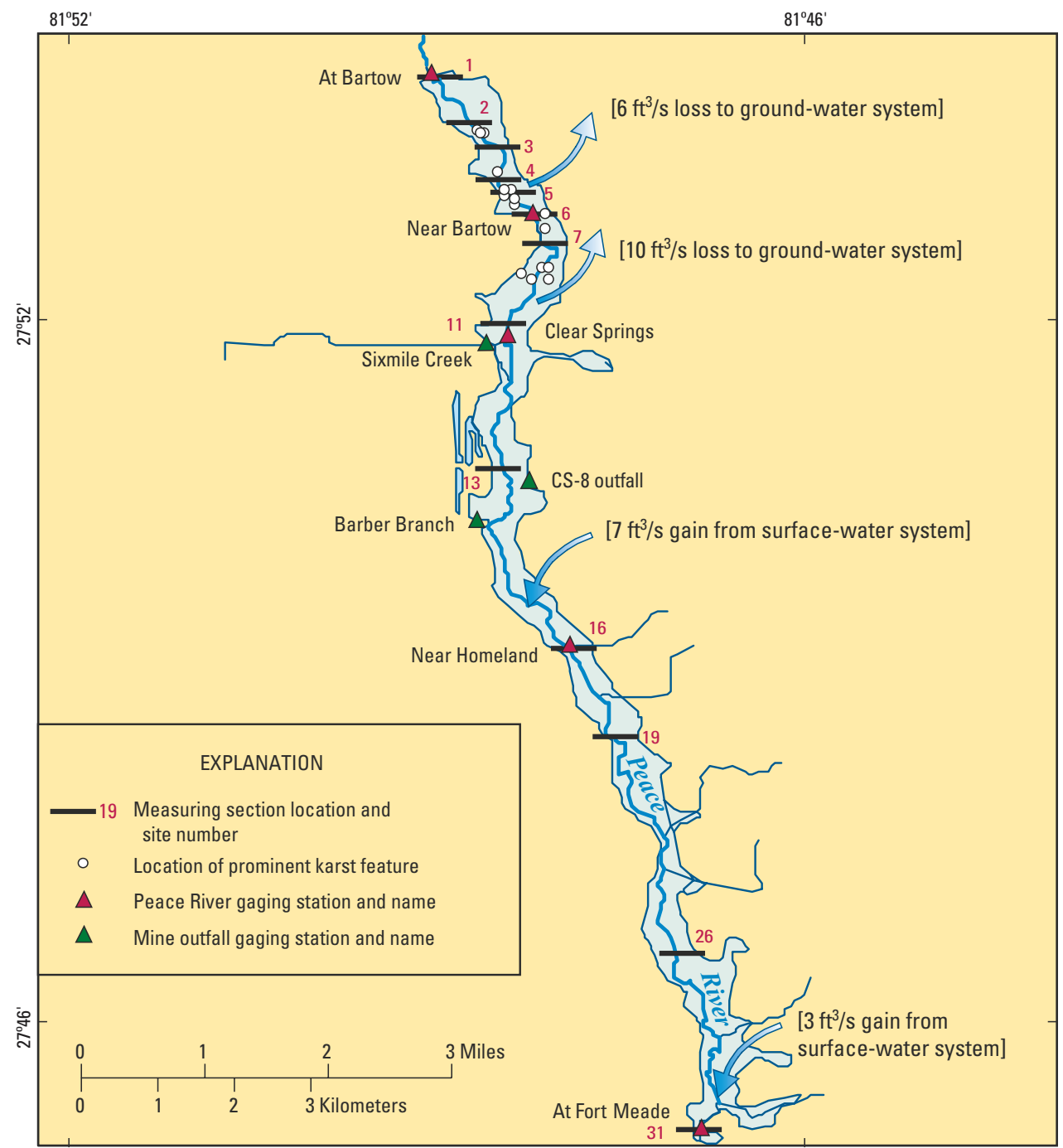

Figure 9. Locations of Peace River cross sections measured during the seepage run May 13-14, 2003. 


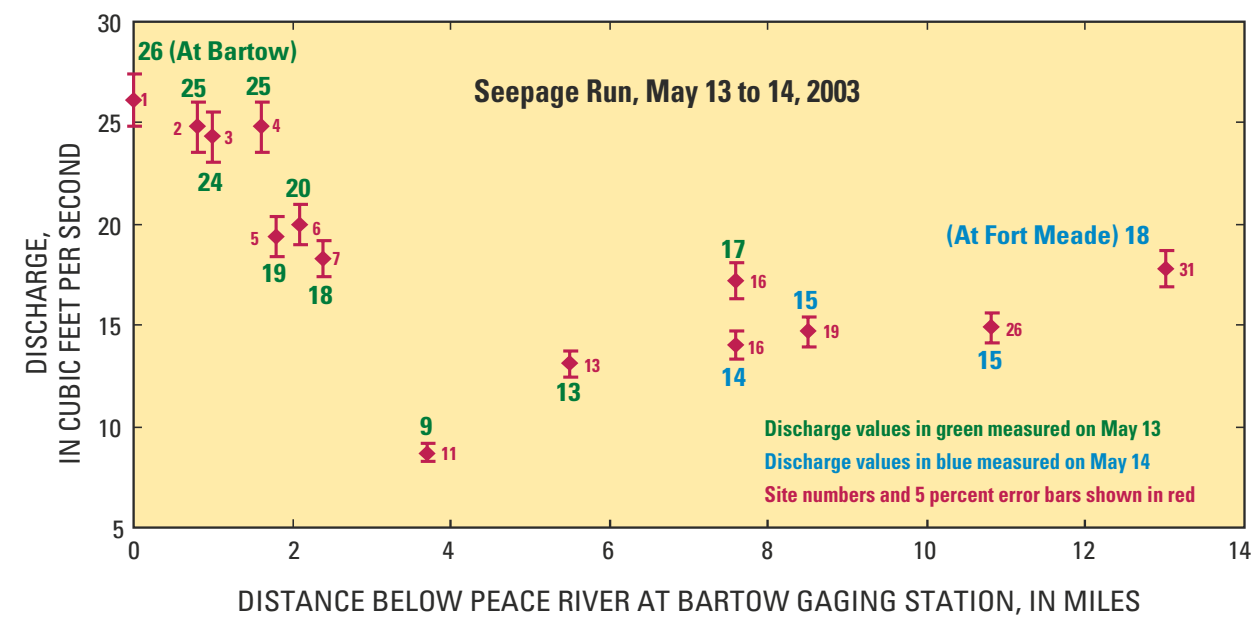

Figure 10. Peace River site numbers, discharge, and error bars for data collected during the seepage run conducted May 13 to 14, 2003.

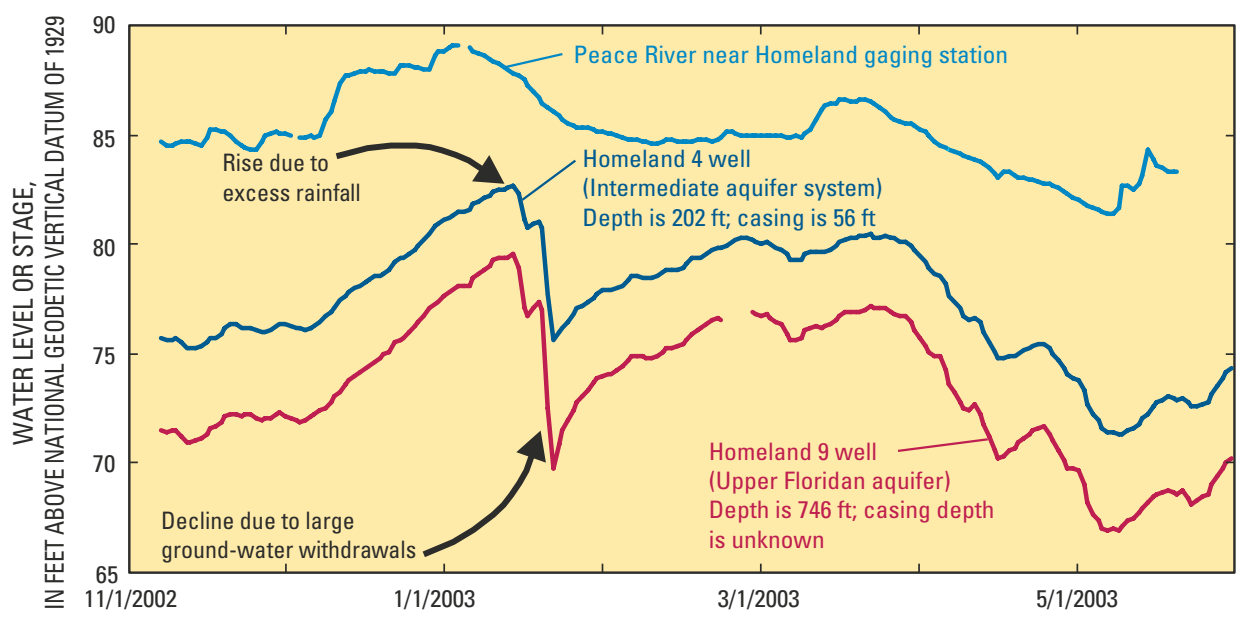

Figure 11. Surface-water stage and ground-water level hydrographs for Peace River near Homeland gaging station and Homeland 4 and 9 wells (November 2002 through May 2003).

Hydrologic Area indicate that water levels in the intermediate aquifer system and the Upper Floridan aquifer were $20 \mathrm{ft}$ lower in May 2002 than in May 2003.

Preliminary analysis of the differences between the stage of the Peace River and head in the aquifers in the Upper Peace River Hydrologic Area was based on data from an existing pair of wells (Homeland 4 and Homeland 9) located within 1 mile of the Peace River near the Homeland gaging station (fig. 1). The wells penetrate the intermediate aquifer system and the Upper Floridan aquifer, respectively, and are the only available monitor wells located in close proximity to the river. The head difference between these two aquifers indicates recharge conditions and is relatively constant at about $4 \mathrm{ft}$ (fig. 11). Water-level hydrographs show that the stage of the Peace River near the Homeland gaging station was higher than the heads in the aquifers, indicating the potential for the river to be a losing stream (fig. 11). The difference between the river stage and the head in the intermediate aquifer system is smaller during the wet season and larger during the dry season, ranging from about 5 to $12 \mathrm{ft}$ (fig. 11). The El Niño-Southern Oscillation condition resulted in above-normal rainfall that was reflected on hydrographs as steeply rising water levels in December 2002 (fig. 11). The dramatic drop in water levels on January 24 to 25 , 2003, resulted from large ground-water withdrawals associated with frost and freeze protection of crops (fig. 11).

\section{Summary}

This fact sheet summarizes the preliminary results determined during the first year of the study and is part of a comprehensive investigation to quantify the streamflow losses in the Upper Peace River Hydrologic Area. Measured streamflow losses did not exceed $30 \mathrm{ft}^{3} / \mathrm{s}$ during the dry seasons of late spring 2002 and 2003. In May 2002, streamflow losses ranged from about 2 to
$30 \mathrm{ft}^{3} / \mathrm{s}$. In May 2003, the aquifer head was $20 \mathrm{ft}$ higher than in May 2002, and streamflow losses did not exceed $16 \mathrm{ft}^{3} / \mathrm{s}$. A factor impeding the quantification of the distribution, timing, and volume of surfacewater to ground-water exchange is the lack of aquifer head data near the Peace River. Several well clusters are to be drilled, sampled, and monitored on the Peace River flood plain where karst features are prominent. The hydrologic data collected from these sites will provide a better understanding of the transient nature of the water exchange between the river and the ground-water system.

\section{Selected References}

Lewelling, B.R., Tihansky, A.B., and Kindinger, J.L., 1998, Assessment of the hydraulic connection between ground water and the Peace River, west-central Florida: U.S. Geological Survey Water-Resources Investigations Report 97-4211, 96 p.

Rantz, S.E., and others, 1982, Measurement and computation of streamflow; vol. 1. Measurement of stage and discharge: U.S. Geological Survey Water-Supply Paper 2175, $284 \mathrm{p}$.

Simonds, F.W., and Sinclair, K.A., 2002, Surface water-ground water interactions along the Lower Dungeness River and vertical hydraulic conductivity of streambed sediments, Clallam County, Washington, September 1999-July 2001: U.S. Geological Survey Water-Resources Investigations Report 02-4161, 60 p.

Stewart, H.G., Jr., 1966, Ground-water resources of Polk County: Florida Geological Survey Report of Investigation 44, $170 \mathrm{p}$.

\section{For further information, contact:}

Lari A. Knochenmus

U.S. Geological Survey

The University Center for Business 10500 University Center Drive, Suite 215 Tampa, Florida 33612-6427

Telephone: 813-975-8620 x160

Fax: 813-975-0839

Email: lari@usgs.gov

For additional copies of this report, please write to:

U.S. Geological Survey

Branch of Information Services

Box 25286

Denver, CO 80225 